\author{
Mona Evelyn Flognfeldt \\ Department of Primary and Secondary Teacher Education \\ Oslo and Akershus University College of Applied Sciences \\ Email: mona.flognfeldt@hioa.no
}

\title{
Professional Feedback Loop: How Can Practising Teachers' Reflection Inform English Language Teacher Education?
}

\begin{abstract}
This article presents a study of the learning reported by practising teachers of English in Norwegian primary and lower secondary schools. The teacher reports were in connection with a year's further-education course in English, which included a pedagogical development project at their own school. This study provides insights into what aspects of the subject the practising teachers defined as their main instructional challenges in the classroom and what their main learning outcomes were. The data for this article are critical reflections articulated by the teachers at the end of their projects. Based on qualitative content analysis, I identified salient language-pedagogical features and commonalities in the teachers' conceptualisations of their role and priorities with respect to student learning. This kind of language teacher research can have important implications for the way English is taught in initial teacher education. Relevant teacher cognitions can be channelled back to student teachers to mediate their professional preparation in the teacher education programme and their future work as English teachers. The central language-pedagogical issues identified in their research can be used as analytical and reflective tools for student teachers in their preparation for the complex practicalities of the classroom. Exploring the research that practising teachers have conducted into challenges they identified can help students connect theory with practice as well as contribute to lowering the affective filter of novice teachers. This article ends with a discussion of possible forms that this professional feedback loop can take.
\end{abstract}

Keywords: english language teacher education, professional development, teacher research and development, teacher learning, language pedagogy

\section{Sammendrag}

Denne artikkelen presenterer en studie av den type laring praktiserende engelsklærere $i$ norsk grunnskole selv rapporterer etter et års videreutdanningsstudium i engelsk. Et pedagogisk utviklingsprosjekt på egen skole inngikk som en sentral del av studiet. Studien gir et innblikk i hvilke aspekter ved skolefaget engelsk som erfarne lcerere definerer som hovedutfordringer i undervisningen og utbyttet de har hatt av prosjektene sine. Artikkelen bygger på data fra den kritiske refleksjonen som larerne gir uttrykk for mot slutten av prosjektene sine. På bakgrunn av kvalitativ innholdsanalyse av prosjektrapportene identifiseres vesentlige felles språkdidaktiske elementer i larernes konseptualisering av sin egen rolle og egne prioriteringer overfor elevenes læring. Denne typen larerforskning kan få viktige følger for opplæringen $i$ studiefaget engelsk i lærerutdanningen. Relevante forestillinger blant praktiserende lærere kan kanaliseres tilbake til læererutdanningen for på den måten å mediere studentenes profesjonsforberedelse og deres framtidige arbeid som engelsklcrere. Sentrale 
språkdidaktiske tema blir trukket fram, som i sin tur kan fungere som analytiske begreper og verktøy for engelskstudentene i forberedelsen til de komplekse praktiske utfordringer i klasserommet. Kontakt med denne typen forskning på egen undervisning som erfarne lerere har gjennomført med fokus på det de opplever som engelskfaglige utfordringer, kan hjelpe lererstudentene til å knytte sammen teori og praksis og bidra til å senke deres affektive filter når de starter som larere. Denne artikkelen munner ut i en diskusjon om hvilke former denne tilbakemeldingen fra praksisfeltet kan ta.

Nøkkelord: utdanning av engelsklærere, profesjonsutvikling, læereres forskning, læreres læring, språkdidaktikk

\section{Introduction}

English language teacher education in Norway in the $21^{\text {st }}$ century is offered in a world of rapid change. These changes concern the conceptualisation of English as a language, the nature of learners in schools and the general languagepedagogical climate in teacher education and among teachers in schools. Firstly, the status and role of English as a language are changing globally, which implies a constant need for renegotiation of its position in local educational settings (Rindal, 2014; Simensen, 2014). This change has consequences for the way English as a subject is defined and taught in Norwegian classrooms, although the process of change at the local level is incremental and slow. Secondly, learners in classrooms in various parts of the country are increasingly multicultural and multilingual (Jessner, 2008; Surkalovic, 2014). Finally, the language-pedagogical climate is dynamic; there is today a concern for differentiated instruction and an appeal to a combined focus on meaning and form within a communicative language-teaching framework (Kumaravadivelu, 2003; Nation, 2007).

In this complex setting, teachers of English start their education and teaching careers with knowledge and beliefs about the language and language teaching that are based on their own classroom experience as language learners, their "apprenticeship of observation" (Lortie, 1975). New knowledge is constructed in the course of their teacher education, only to be challenged by the practicalities and language-pedagogical culture at the school where novice teachers start working. The transition from being a student to working as a teacher can be quite overwhelming. It is sometimes characterised as a reality shock for many novice teachers (Farrell, 2003). In fact, research has shown that newly qualified teachers spend much of their time negotiating the challenges of classroom management and pupil control; in contrast, more experienced teachers are able to direct their efforts towards language-learning management with a focus on the purpose and objectives of the subject (Flognfeldt \& Chvala, 2013; Farrell, 2015a; Lampert \& Graziani, 2009). Based on the present research into what a group of practising teachers of English saw as their main instructional 
challenges combined with their reported new insights after a development project in their own classroom, I aim to look into possible implications for initial language teacher education.

As the title of the article indicates, I see this process of channelling experienced teachers' learning back to the field of initial teacher education as a professional feedback loop. The feedback loop concept is central in studies of complex systems (Cochran-Smith mfl., 2014). It also calls to mind the cyclical process of action research methodology, with its repeated cycles of planning, action, observation and reflection (Borg \& Sanchez, 2015). My aim as a teacher educator is to mediate the process of feeding teacher research back to student teachers in the form of learning resources for use in their professional preparation. Before sharing my findings and their possible implications for teacher education, I briefly discuss some of the central concepts that have emerged in the field of teacher cognition.

\section{Theory}

The $21^{\text {st }}$ century has witnessed a boom in international research on language teacher education (Ball \& Forzani, 2009; Borg, 2006, 2012; Borg \& Sanchez, 2015; Farrell, 2015b; Freeman, 2002). When researchers talk about language teacher education, they often have the professional study in mind for students who are enrolled in initial teacher education programmes, whether at a university or a college of education. Programmes vary in the way practicalpedagogical training is either given as a separate course after the completion of subject studies or is integrated in the subject course as applied perspectives throughout. However, it seems fair to say that the extensive body of research on teacher learning spans a broader field of teacher education, addressing the experiences of both student teachers and practising teachers, the latter often engaged in continuing professional development. Recent contributions to the field have offered state-of-the-art summaries of central topics of concern (Barnard \& Burns, 2012; Borg \& Sanchez, 2015; Farrell, 2015b). Teacher learning and teacher cognition stand out as salient constructs in the literature, with a recurring focus on teacher beliefs.

The construct teacher cognition refers to teachers' knowledge, assumptions, beliefs, values and emotions. Teacher cognition deals with the mental lives of teachers, the unobservable aspects of their pedagogical actions in the classroom. From a language-pedagogical perspective, some studies have examined beliefs about subject-specific themes like grammar (Giovanelli, 2015; Watson, 2015), vocabulary (Hestetræet, 2010; Macalister, 2012) and communicative proficiency (Lampert \& Graziani, 2009). The majority of studies into teacher cognition, however, have been more generic, investigating the impact of professional communities on teacher learning (Avalos, 2011; Vescio, Ross, \& Adams, 2008) 
and reporting considerable benefits when school leaders are involved in teachers' continuing professional development (Desimone, 2009; Maugesten \& Mellegård, 2015; Opfer \& Pedder, 2011).

In fact, a considerable body of research has stressed the value of collaborative teacher research and learning in strong communities of practice (Flognfeldt, 2015; Avalos, 2011; Barnard \& Burns, 2012; Borg \& Sanchez, 2015; Postholm, 2012; Putnam \& Borko, 2000; Vescio mfl., 2008). As will be clear from this study, my focus has been on individual teachers' professional development and their reflections on new classroom practices. Other important factors for effective teacher learning are reflective practice (Zeichner, 2008) and the development of extended professionality, understood as deeper learning and a constant drive towards improved practice and development (Evans, 2010).

Borg (2011) held that teacher education is more likely to have an effect on student teachers' classroom practice if it also has an effect on their beliefs about teaching. Researchers have defined beliefs in various ways depending on perspective, but the following is basic to Borg's own use of the term:

Beliefs are propositions individuals consider to be true and which are often tacit, have a strong evaluative and affective component, provide a basis for action, and are resistant to change (p. 371).

In his study, Borg wished to discover what impact an eight-week full-time further-education (in-service) course had on the beliefs of practising teachers of English as reported by these teachers through a series of interviews. Based on the gathered data, Borg recommended making reflection on beliefs a "central social teacher learning process by providing communal opportunities - e.g. inclass discussions - for teachers to talk about their beliefs” (Borg, 2011, p. 379).

As a result of a mapping study of what student teachers, teacher educators, school-based mentors and policy makers rated as the strongest influences on student teachers' learning, Cochran-Smith mfl. (2014) found students' personal beliefs to be the first of three central elements. The other two essential factors were mentor teachers and learners in classrooms. In a state-of-the-art review of research on practice in second-language teacher education, Wright (2010) recognised an emerging language pedagogy characterised by (a) an emphasis on student teacher cognition, (b) reflective practice, (c) inquiry into students' own beliefs, narratives and professional contexts, and (d) a focus on learning from experience (p. 273).

In a Norwegian context, Haukås (2014) referred to research on teacher cognition and looked at factors influencing student teachers' beliefs about language teaching and what it takes to change often resistant beliefs. When changes were identified, Haukås (2014) reported that they occurred where student teachers had developed an awareness of their existing assumptions, by discussing them with others and trying them out in practice. In a similar manner, 
Postholm (2012) presented various theories, perspectives and practical examples of teacher learning, including a review of how experienced teachers learn (Postholm \& Rokkones, 2012). Based on their research, the authors claimed that formal further education with opportunities for exploratory work in teachers' own classrooms appears particularly fruitful with respect to their own and their pupils' learning. Another positive outcome is that teachers develop a research attitude to their own professional practice.

Student teachers start out with beliefs based on their own experience. After a substantial number of years as students themselves at the feet of their teachers, it is to be expected that this experience has left traces in their minds. At the same time, beliefs are often tacit and hard to elicit. In a teacher education setting where subject matter and ideas about its application for teaching purposes are integrated, students will have beliefs about English as a language, as a subject for study, and as a school subject with a curriculum to be enacted in the classroom. Student teachers, then, do not start their education from scratch. In the course of their education programme, they have opportunities for field experience on a regular basis. Thus, their beliefs may be challenged and possibly changed before they are certified teachers. To facilitate change, beliefs may need to be made explicit. According to Freeman (2002):

if teachers' mental lives are storied or narrative webs of past and present experience, if their knowledge is reflective of their position in the activity of teaching, then it makes sense that reflective practice must become a central pillar in teacher education (p. 11).

As it happens, students often argue that the world of teacher education on campus and the world of their practicum do not align well enough. Even in courses where subject content is taught with a focus on teaching and learning, students tend to deplore a disconnection between theory and practice (CochranSmith mfl., 2014; Sjølie, 2014; Warford, 2011; Zeichner, 2010). This is another reason why they may gain significantly from sharing practical insights from more experienced others as well as engaging in their own teaching practice.

According to Borg (2011), there has been little research into how further teacher education impacts on the beliefs of teachers taking part in further education courses for language teachers. Like his research, this study seeks to redress this imbalance. If beliefs are indeed a key element in teacher education, to be consolidated or changed through coursework and teaching practice experience, a useful step would be to integrate elicitation and explicit discussion of beliefs as part of the programme for prospective English teachers. With this study, I aim to suggest a way of connecting the school space and teacher education by building on the experience of practising teachers.

Moreover, if reflective practice is a "central pillar in teacher education" (Freeman, 2002, p. 11), reflective skills need to be taught and developed from the start. Students will need to acquire a vocabulary and professional discourse 
to enable them to articulate their experience and their emerging professional knowledge (Brevik, Fosse, \& Rødnes, 2014). Articulation and reflection are thus reciprocal processes. Freeman (2002) referred to this as a process of renaming. One possible interpretation is that students get an opportunity to reconceptualise and make explicit their previous experience as learners, fusing it with their own newly acquired practical experience from the classroom and the new knowledge they construct from the content of their theoretical study on the course.

Teacher educators are concerned with the professional preparation of prospective English teachers and how that can be made as formative and effective as possible. I contend that the reports from the experiences of practising teachers can be used in a teacher education programme to good effect, both cognitively and affectively. Having a chance to share what practising teachers report about real-life classroom challenges and the steps they have taken to meet these has great potential as content in the language-pedagogical part of courses. With this practically defined purpose, the key research questions addressed in this study are:

1) What aspects of English as a school subject do practising teachers see as their main instructional challenges?

2) What changes and beliefs do these teachers report as a result of pedagogical development projects in a further-education course?

\section{Materials and Methods}

This study took place among 22 teachers taking part in a further-education course in English. The methodological orientation of the study is qualitative, since my primary aim is to explore the participants' reflection and learning in an attempt to understand the complexity of their professional experience.

Because my study was not designed as a research project from the outset, the sample of participants was based on convenience rather than randomised selection (Borg, 2012). The informants in this project were teachers earning the remaining 30 credits in English required for employment as a subject teacher in secondary school, the minimum qualification being 60 credits (equalling one year's full-time study). They were teachers from across Norway whose participation in the course was supported by their local principal. The course English 2 (5-10), targeting years 5-10 in basic education, was offered as part of the national further-education strategy Kompetanse for kvalitet ("Competence for Quality”). It was a blended course, consisting of web-based interaction combined with face-to-face gatherings.

The participants' coursework consisted of various online deliveries of oral and written course requirements. Essential parts of this kind of further-education course are English subject matter and language-pedagogical content, assessment, 
adapted instruction and the pedagogical use of ICT tools. Alongside the written and oral course requirements, the teachers planned and carried out a pedagogical development project (PDP) in their own classroom. Though not restricted to an action research design, the participants were encouraged to see their project in the classroom as one cycle in a process and required to articulate what their next step would be if they were to continue their project (Burns, 2014). These PDPs were individual, giving the participants a chance to plan, carry out and reflect on their own personal professional development. According to Borg and Sanchez (2015), teacher projects count as research only if they are made public. In the context of this study, the participants submitted their written project reports as a part of the final exam, which also included an oral examination where participants presented and discussed their results. In other words, the reports were not entirely private documents for the eyes and ears of the course examiners only. The question whether research into teachers' own practice is research or not has been debated in the literature. However, the value of teachers' work does not rest on this definition; it constitutes a new kind of scholarship articulated by people who really know the realities of the classroom and the challenges involved in teaching (Anderson \& Herr, 1999).

The practising teachers were not involved on a voluntary basis, since phases of their project were course requirements. They received a list of suggested topics for their PDPs. Assessment of their pupils' learning was mandated as an integral part of all the topics. The rationale behind this was a wish to make the teachers produce more than anecdotal ideas about what worked and what did not. The teachers were encouraged to focus on one of the basic language skills, or a subskill like vocabulary development or grammar. Guidance was offered at various stages in the process. The reports were graded after being presented in groups. Another teacher educator was present at the oral examination as a coexaminer, assessing both the reports and the oral presentations.

The following phases of the PDP were carried out: The participants were given model texts, a list of topics addressed by a previous cohort of teachers, a visit by two previous participants sharing their experience, and written instructtion including the required components of the final report. The teachers were instructed to consult one source of knowledge about language pedagogy in addition to syllabus material. The course required participants to submit a written planning document in the autumn term, followed by an oral report on work in progress in the early spring term. In general, work in the classroom took place from February through April, with reports being submitted in the middle of May and the oral discussion at the beginning of June.

In terms of key ethical concerns in educational research, voluntary informed consent was obtained from all the participants in the study. Both their anonymity and the confidentiality of the data have been protected. All the authors have been given fictitious names. The reports were already anonymous, since they were delivered as exam papers. I was their tutor during the project, so complete 
anonymity in relation to me was not possible along the way. As a teacher educator, I was centrally involved in the whole course, but since no claims of generalisability are made in this study, I do not see this as a problem.

\section{Data Collection and Analysis}

This study was a small-scale investigation of the critical reflection part of the PDP reports described. Ary, Jacobs, and Sorensen (2010) refer to an investigation of written documentation like these reports as content or document analysis. In order to answer my two research questions, I selected the parts involving critical reflection for detailed study, on the grounds that this final part would be a likely source of new insights. In addition, any discussion of a solution to the challenges these teachers had chosen to address was likely to appear in this part of the reports. Each text was thematically coded by means of the research software NVivo, guided by my research questions. Based on each text and its associated project title, categories emerged from the initial coding that gave a clearer picture of what English-pedagogical issues the teachers were struggling with. A few examples of thematic codes and nodes to emerge in my analysis are "grammar in writing", "inspiration from literature", "reading strategies", "vocabulary", and "feedback between drafts".

To address the second research question, I scrutinised the documents primarily for statements of conviction. In the process, I took sentence starters like "I believe ..." and "I think ..." as well as evaluative adjectives/adverbs like "strong(ly)" and "important" to be indications of beliefs (Borg, 2011). Since the purpose of the PDP was to instigate development and hence some kind of change, passages including the word "change" and semantically related words were coded to the node "change". In the coding process, other exponents emerged as relevant as well, for instance, "I learnt" and "come to a better understanding”.

\section{Validity/Transferability and Limitations}

Questions may arise about the generalisability of the findings of this study and their proposed application when fed back to language teacher education. With the subjective nature of the interpretative research paradigm and the complexity of educational contexts and processes, I am aware of the limitations of a study like the present one. The most important point to keep in mind, however, is that the analysis was initiated in order to fill local needs, not to make general claims about language teacher cognition (Borg, 2012).

Oolbekkink-Marchand, van der Steen, and Nijveldt (2014) followed Anderson and Herr (1999) in arguing that practitioner research requires a conception of validity that responds to the kind of conditions and purposes relevant to this kind of research. A central purpose and a sign of the quality of teacher professional research is improved practice, that is, change for the better in the way teaching is enacted. For this reason, one possible criterion of quality 
in practitioner research like the teachers' and my own is catalytic validity. This criterion concerns the degree to which the research is oriented towards transformation of practice. Another measure of rigour in qualitative research is whether one's findings are considered credible (Ary mfl., 2010). Credibility relates to whether the realities of the other research participants are represented as accurately as possible. In addition, findings should be dependable or trustworthy. One way of securing these qualities is by making one's report transparent, describing the research process and participants as adequately as possible so that other researchers will be able to recognise similarities and make judgments about transferability.

\section{Findings}

In this section, I present the findings relevant to the aspects of English that the 22 teachers saw as their main instructional challenges, based on their choice of topics for their PDPs. Then I report the findings in response to my second research question concerning what the teachers expressed as their main changes and beliefs. It is important to keep in mind that the teachers were not instructed to explicitly report on possible changes in their beliefs.

The titles of the different projects varied in length and degree of precision. Table 1 is a rewording of the various project titles into a more uniform representation, a translation into specific language-pedagogical challenges. As already mentioned, all the projects had to include documentation of pupils' work. A quick note is necessary to explain what is meant by SMART targets, since it stands out in three of the entries: The word SMART is an acronym for the following characteristics of effective corrective feedback to emerging listeners, speakers, writers or readers of English: $S$ (specific), $M$ (measurable), $A$ (achievable), $R$ (relevant) and $T$ (time-related). This way of giving feedback was taught as part of the course content on assessment.

The most prominent instructional challenge for this group of teachers was the development of their pupils' writing. A simple count of the topics listed demonstrates that 15 out of 22 teachers chose to target writing. Two teachers chose to work with reading (Andrea and Johanne), two with speaking (Marie and Siri), and the last three with vocabulary development (Martin), drama (Sara), and a comparison of two teaching methods (Jakob).

A general tendency is evident in my material. Improving teaching practice in order to enhance pupil learning is a matter of procedural teacher knowledge. Developing their declarative knowledge of the various systems of the English language, grammar, lexis, phonology and discourse, for instance, is not a key issue here. This is only to be expected, given the nature of the project as pedagogical development, with the aim to enhance classroom practice. Still, Martin chose to target vocabulary acquisition, and Live and Berit were con- 
cerned about aspects of grammar, notably subject-verb concord with the verb be and various irregular verbs.

\section{Table 1}

Challenges Targeted by Practising Teachers in Their Pedagogical Development Projects

\begin{tabular}{|c|c|}
\hline Teachers & Focus of Pedagogical Development Project (PDP): Challenges \\
\hline Nora & Improving writing skills, using assessment for learning \\
\hline Solveig & Improving writing skills, facilitating self-assessment \\
\hline Eli & $\begin{array}{l}\text { Improving the structure of narrative texts, doing process writing incorporating } \\
\text { SMART targets }\end{array}$ \\
\hline Vera & Writing texts inspired by literature (poems and nursery rhymes) \\
\hline Maren & $\begin{array}{l}\text { Developing writing skills, using fixed phrases and oral speech in the pre- } \\
\text { writing phase }\end{array}$ \\
\hline Peter & $\begin{array}{l}\text { Improving writing skills, helping } 8^{\text {th }} \text { graders, focusing on appropriate use of } \\
\text { verb tense }\end{array}$ \\
\hline Gry & $\begin{array}{l}\text { Improving writing skills, building cohesion and fluency through the use of } \\
\text { connectors, including task analysis }\end{array}$ \\
\hline Lilja & Doing process writing, using SMART target assessment \\
\hline Live & Improving writing, focusing on subject-verb concord (to be) \\
\hline Berit & Improving writing, motivating pupils to learn irregular verbs by heart \\
\hline Martin & $\begin{array}{l}\text { Facilitating vocabulary (high-frequency words) acquisition, using a cognitive } \\
\text { approach }\end{array}$ \\
\hline Tuva & $\begin{array}{l}\text { Developing writing, using formative assessment, trying to motivate learners to } \\
\text { write longer texts (blogs) }\end{array}$ \\
\hline Cecilie & Improving writing skills, using blogs as a tool \\
\hline Andrea & $\begin{array}{l}\text { Improving reading comprehension by means of scaffolding techniques like the } \\
\text { story map }\end{array}$ \\
\hline Bente & $\begin{array}{l}\text { Improving writing skills, using process writing and assessment for learning by } \\
\text { means of SMART targets }\end{array}$ \\
\hline Guri & Developing writing skills, by means of assessment and the use of literature \\
\hline Marie & Developing speaking skills \\
\hline Johanne & $\begin{array}{l}\text { Developing reading comprehension, reading strategies and metacognition } \\
\text { about reading }\end{array}$ \\
\hline Siri & $\begin{array}{l}\text { Developing fluency in speech, by means of speed dating about picture books, } \\
\text { using task repetition }\end{array}$ \\
\hline Ellen & Developing writing skills, using formative assessment as a tool \\
\hline Sara & Facilitating vocabulary learning and use by means of drama as a method \\
\hline Jakob & $\begin{array}{l}\text { Comparing the effectiveness of guided reading and cooperative learning as } \\
\text { teaching methods }\end{array}$ \\
\hline
\end{tabular}

I have chosen to concentrate on findings connected to the languagepedagogical theme of writing in response to my first research question, since most of the teachers chose this area of professional development.

\section{The Development of Writing Skills in English}

Most of the teachers reported on improvement in their pupils' writing, as demonstrated in these two examples: 
When I look at the texts that were produced during this project I am really pleased. I see that all of my students have benefited from this work and hopefully during this process they have built themselves a better writing habit. (Nora)

In addition to having improved their writing skills, I will say that they also have improved their reading and communication skills. (Cecilie)

Nora expressed concern about the awareness her students may have developed in the course of the writing process, for possible strategic use in later tasks. Cecilie stated that her pupils had made gains in other skills in addition to writing. It is likely that their growing awareness of what the writing process implies is transferable as a more strategic way of working. This was implied when two other teachers came to realise that pupils sometimes do not understand what they are supposed to do in a writing task:

One of the things I have learned during this project is that sometimes I think we might misunderstand our pupils' understanding of texts and are led to believe that they understand more than they actually do. Maybe we take some knowledge for granted? I have experienced that I need to focus more on reading comprehension and make the pupils develop good strategies for themselves. (Gry)

I will use my knowledge from this project to be more attentive to the assessing of pupils understanding of information given so that my next teaching act can be matched to the present understanding of the pupils. (Bente)

The importance of understanding what a writing task really asks of the learner made these teachers anxious to help their students develop more effective reading strategies.

In order to illustrate some of the multiplicity of the theme of writing, Figure 1 represents a kind of summary. It is an aggregate of the participants' critical reflections on this topic. More than the nature of writing itself, the figure presents some of the key thematic factors involved in writing. As can be seen from Figure 1, I have chosen to subsume factors under broader languagepedagogical themes that are relevant to writing. The following categories seem fruitful: process, product, strategies, tools, motivation and assessment. Writing is a process that ends with a product. This product has a structure, a certain size, content, style, etc. Various strategies are involved in the writing process, and different tools may be useful in various stages of the process. Social or affective factors may motivate the writer, not least to get started in the first place. Since the writing process takes place at school, the kind of assessment and feedback given by the teacher may be a facilitative factor. What the model does not show is that writing is always embedded in a context. I do not see context as external to the process, but rather as dynamically shaping and being shaped by it (Cochran-Smith mfl., 2014).

This overview has emerged from my interpretation of one particular set of reflections; it is not taken to be exhaustive in any other sense. I hasten to add 
that the categories are not discrete either; there are obvious interconnections between them, as will be clear from this teacher's comment:

For some learners it can take more time than for others to decide what to write, and to remember the vocabulary they actually are possessing. We had brainstorming on the blackboard with suggestions in addition to having a page in the blog forum with a list of suggestions from students and teachers. (Cecilie)

Features concerning motivation (how to get started), stages in the writing process (pre-writing), strategies (brainstorming ideas and possibly useful vocabulary) and tools (a list of suggestions) are all closely interrelated.

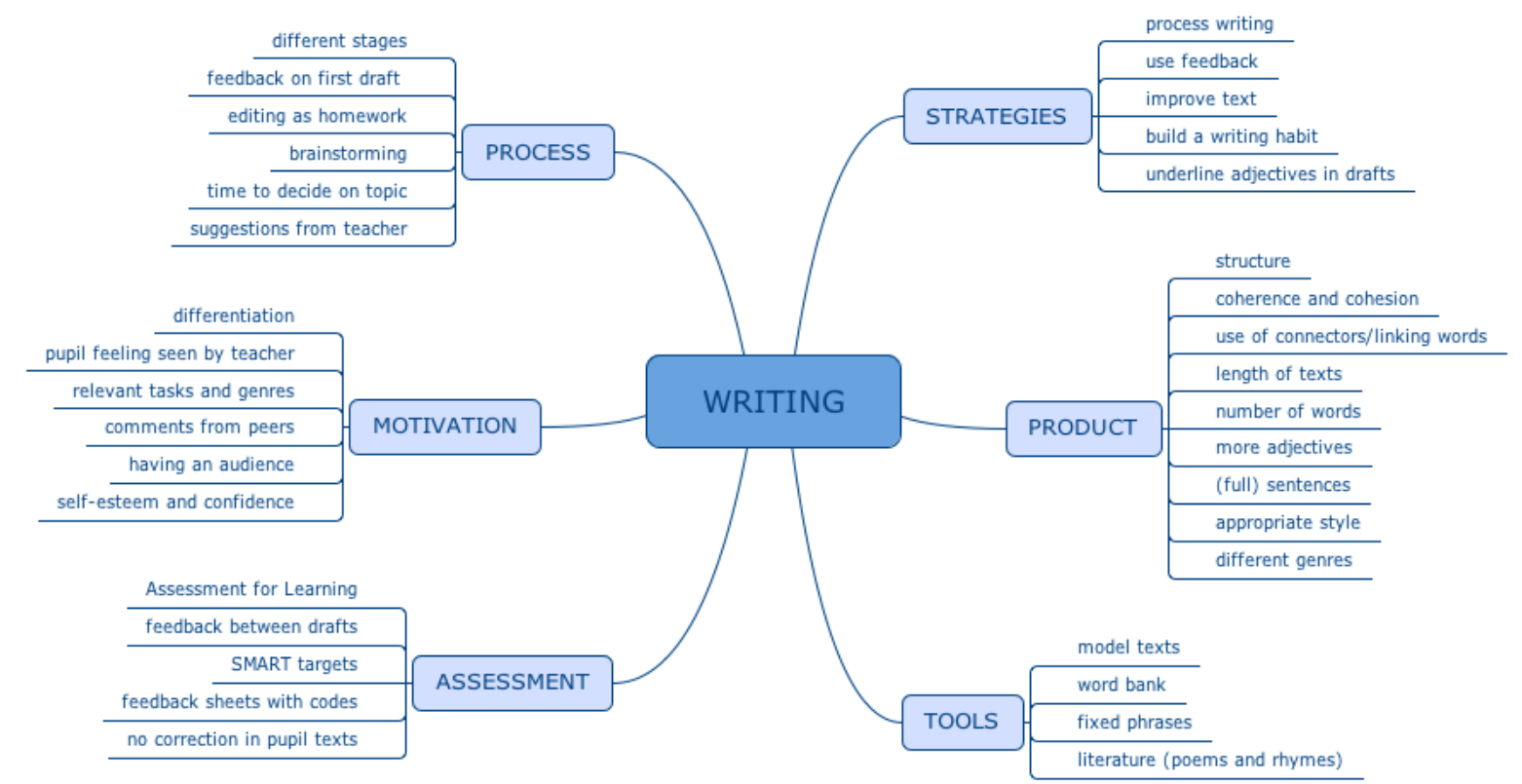

Figure 1. Concept map of the professional theme of writing. I developed this concept map from data based on the critical reflections in the 15 project reports focusing on writing.

These core elements are useful for me as analytical categories in my attempt to understand the teachers' priorities and learning outcomes when it comes to pupils' writing development. Space does not permit an extensive interpretation of all the features listed. Based on their critical reflections, I have selected three features as salient since they were singled out by more than one teacher: (a) the importance of giving constructive feedback in the course of the writing process rather than at the end ("feedback between drafts"), (b) quantity of text as evidence of improved writing ("length of texts", "number of words" and "more adjectives" in a narrative text), and (c) a concern for the quality of the texts in terms of coherence and cohesion ("structure", "coherence and cohesion", "use of connectors/linking words").

Regarding (a) feedback during the process of writing, results were convincing for the teachers: 
The small bit of research I have done on the subject suggests that this [i.e. theory read on the course] is true. The students that I picked out did improve their writing during this process. (Nora)

I also need to change the focus on when I give them their main assessment till sometime in the middle of their writing process rather than at the end. (Ellen)

As these quotes illustrate, Nora expressed that her own experience corroborated the research she conducted for her project. Ellen, in turn, reached the conclusion that she had to change her previous practice and start giving feedback between drafts.

The second central feature in this material is that (b) improved writing is frequently associated with quantity. Participants took the fact that pupils increasingly produced longer texts as a sign of success:

Yet, I have to say that when it comes to producing sentences and texts of some length this project has been partly successful. (Peter)

Peter referred to a certain length as a success criterion. In addition to length, many of the reflections revealed that the teachers felt a need to work on motivation. Tuva introduced the blog as a text type, thinking her pupils would enjoy writing their own blog posts. Even though she was happy to report on more words being written, she demonstrated awareness that quantity can have its price:

Even though they now are able to write longer texts, it does not mean that they have reached the competence aims [...] They might not have developed their language skills in terms of coherence and cohesion, so we still have a lot of work to do. (Tuva)

Writing longer texts, according to Tuva, must be weighed against fulfilling other aims in connection with written communication, such as coherent messages. The following quote echoes this concern for (c) text coherence and cohesion:

Using SMART targets in process-writing as assessment for learning to improve writing skills focusing the use of linking-words ... turned out be successful at least for two of the target pupils. (Bente)

Although Bente wished to report on the benefits of her specific and targeted feedback, she linked that result to the use of cohesive ties like "linking-words".

\section{Change of Practice and Beliefs}

When it comes to findings relevant to my second research question, it is possible to report on change and new beliefs separately. My initial search focused on words like "change", on the one hand, and sentence starters like "I believe ..." and "I think ...", on the other. Close analysis revealed that words and lexical chunks like "review", "rethink", "come to a better understanding”, and "have 
already incorporated" also implied the notion of change. However, some of these statements also expressed beliefs. A distinction can be made between reflections that referred to transformed practice, on the one hand, and new ways of validating and conceptualising actions, on the other, the last one being a defining feature of beliefs (Borg, 2011). However, the two seem difficult to separate.

The following excerpt referred to a new way of thinking:

The reading I have done during the process has changed the way I think about assessment. [...] My next area of focus will be the feedback I give. SMART-targets are something I want to focus on and I think I can continue improving my feedback by using it. (Nora)

Nora linked her decision to improve her feedback to pupils to the knowledge she had acquired from reading theory in the course of her project.

The following are a couple of fairly strong messages about the more practical changes reported by some of the teachers:

I found that the pupils liked the way I gave them feedback, and I will continue using the colour correction codes in the future combined with oral feedback. (Gry)

I have already incorporated the SMART target thinking in all my feedback in all the subjects I teach.... (Lilja)

In these examples, the changes include Gry's new feedback technique and Lilja's extension of the practice she found effective in English to other subjects as well. In her own words, she was already applying her new knowledge.

The following are explicit affective propositions of belief, introduced by the phrase "I (strongly) believe":

Considering the small steps my students managed to take during these three lessons, I strongly believe that with more time and practise and with a more differentiated plan they will show even further development both in their writing and speaking skills. (Maren)

I believe concentrated periods of writing such as this project can help all types of pupils improve, even the pupils that are good writers. (Peter)

Maren was convinced that enough time and differentiated attention was of the essence, and Peter expressed a belief that focused and concentrated efforts can produce deeper learning for all pupils. 


\section{Discussion}

I discuss the findings of my investigation in the light of possible implications for initial teacher education. These findings reveal both the most felt professional challenges and how teachers' PDPs led to changes in the way participants facilitated the development of English language skills. The fact that so many teachers chose to target writing may be due to convenience, since it is easier to trace evidence of concrete interventions in written texts. However, when the teachers referred to improvement in quantitative terms, as longer texts, it seems likely that writing was a felt challenge.

There was evidence of change in the beliefs for some of the students in the group. According to Borg's (2011) definition, teacher beliefs are often tacit, resistant to change, strongly evaluative and affective. A problem with my investigation is that these teachers' pre-project beliefs were never elicited. Thus, I cannot draw any firm conclusions about new beliefs from the reports. However, it is reasonable to infer that beliefs expressed in the critical reflection at the end of a project are indeed new realisations. Some of the beliefs were no longer tacit; they became explicit and may have changed as a result of the teacher's efforts (Borg, 2011).

Returning briefly to the four thematic areas that Wright (2010) recognised as an emerging language education pedagogy (i.e., an emphasis on student teacher cognition, reflective practice, enquiry into student teacher cognition and experiential learning), I would argue that my findings can indeed be used as a basis for course material for student teachers. A concept map like Figure 1 can be used as a mediating tool in a workshop on teaching writing. The core features may serve as focal points in the elicitation of the students' beliefs about the process of writing in English. This way of breaking teaching practice into parts may offer professional terminology for metacognition about teaching and learning (Brevik mfl., 2014; Zeichner, 2008). This model can in turn be used as a research-based conceptual tool in student teachers' planning and reflection in connection with their own teaching practice. Researchers have highlighted reflective practice as crucial for teacher learning (Freeman, 2002; Wright, 2010; Zeichner, 2008). It seems likely that sharing the experience of teachers who are deeply embedded in school contexts will be more conducive to challenging student teacher beliefs than research referenced in course books and taught as theory (Sjølie, 2014; Zeichner, 2010). Encountering reflective practice through the voices of practising teachers will also show student teachers how these professionals have developed a research attitude to their own practice (Evans, 2010; Postholm \& Rokkones, 2012). This is an essential element in continuing professional development for teachers.

Ideally, the professional feedback loop I have suggested here, supplying a bridge from the world of practising teachers back into initial teacher education, is one way of reconnecting theory and practice. It may seem strange that I am 
making rather a lot out of the experiences of teachers who are not directly involved with our student teachers as their mentors. How can someone else's reflections benefit students in their professional preparation? It is my contention that the experience articulated by these practising teachers is beneficial, not least because it is couched in language that is not too overwhelming.

Cochran-Smith mfl. (2014) argued that systematically addressing how beliefs and practices interact as "key leverage points" is important in initial teacher education (p. 118). If a student teacher arrives at a new insight about teaching and learning, this may trigger a change in his or her belief. One way of facilitating this process is enabling student teachers to study reflections on practice provided by teachers with an instruction to look for, recognise and then formulate statements that express beliefs. This kind of text or discourse analysis will constitute a noticing and awareness-raising type of task. At this point, it is other people's beliefs that are being scrutinised. A next step would be to ask the student teachers to compare these beliefs with their own ways of thinking, thus calling on them to articulate their own beliefs. Borg (2011) noted that students may need scaffolding in this process. They should also be encouraged to take a critical stance, questioning their own and others' beliefs. In addition, it is important that the students realise what beliefs are and how they differ from practices and from theoretical knowledge (p. 379).

Whether sustained gains or lasting effects on classroom practice are indeed the result of the teachers' development projects in my study remains to be seen. The minute they return to their every-day complex school realities, it may not be so easy to enact their new practices. In fact, quite a few of them prefaced their decisions about future practice using the adverb "hopefully". More immediately, however, further research is needed to investigate how the results of my study can in fact be used in initial teacher education programmes. It is my aim to take that step in the next study year.

\section{Conclusion}

This article has reported a study into practising English teachers' professional research into their own work with a focus on language-pedagogical challenges. I identified central and common themes about pupils' learning and their development of language skills, with a focus on writing. Teachers' own articulation of beliefs and changes showed their way of thinking and conceptualising learner needs and aspects of teaching and learning English. I offered arguments based on these reports for the concrete innovation that initial language teacher education can benefit from building on these insights, not least using the practising teachers' themes and reflections as heuristic tools.

Further research is needed to discover to what extent a concept map like the one developed here on the basis of teachers' reports about their work with 
writing development can be used as an analytical and reflective tool with student teachers. In addition, future research could determine whether a close study of expressed beliefs about changes of practice and new ways of conceptualising teaching and learning English works as a learning resource in initial language teacher education.

\section{References}

Anderson, G. L. \& Herr, K. (1999). The New paradigm wars: Is there room for rigorous practitioner knowledge in schools and universities? Educational Researcher, 28(5), $12-21+40$.

Ary, D., Jacobs, L. C., \& Sorensen, C. (2010). Introduction to research in education. Belmont: Wadsworth, Cengage Learning.

Avalos, B. (2011). Teacher professional development in Teaching and Teacher Education over ten years. Teaching and Teacher Education, 27, 10-20.

Ball, D. L. \& Forzani, F. M. (2009). The work of teaching and the challenge for teacher education. Journal of Teacher Education, 60, 497-511.

Barnard, R. \& Burns, A. (Eds.). (2012). Researching language teacher cognition and practice: International case studies. Bristol: Multilingual Matters.

Borg, S. (2006). Teacher cognition and language education: Research and practice. London \& New York: Bloomsbury.

Borg, S. (2011). The impact of in-service teacher education on language teachers' beliefs. System, 39, 370-380.

Borg, S. (2012). Current approaches to language teacher cognition research: A methodological analysis. In R. Barnard \& A. Burns (Eds.), Researching language teacher cognition and practice (pp. 11-47). Bristol: Multilingual Matters.

Borg, S. \& Sanchez, H. S. (2015). Key issues in doing and supporting language teacher research. In S. Borg \& H. S. Sanchez (Eds.), International perspectives on teacher research (pp. 1-13). Houndsmill, Basingstoke: Palgrave Macmillan.

Brevik, L. M., Fosse, B. O., \& Rødnes, K. A. (2014). Language, learning, and teacher professionalism: An investigation of specialized language use among pupils, teachers, and student teachers. International Journal of Educational Research, 68(46-56).

Burns, A. (2014). Professional learning in Australian Elicos: An action research orientation. English Australia Journal, 29(2), 3-20.

Cochran-Smith, M., Ell, F., Grudnoff, L., Ludlow, L., Haigh, M., \& Hill, M. (2014). When complexity theory meets critical realism: A platform for research on initial teacher education. Teacher Education Quarterly, Winter 2014, 105-122.

Desimone, L. M. (2009). Improving impact studies of teachers' professional development: Toward better conceptualizations and measures. Educational Researcher, 38(3(April)), 181-199.

Evans, L. (2010). Developing the European researcher: "Extended" professionality within the Bologna Process. Professional Development in Education, 36(4), 663-677.

Farrell, T. S. C. (2003). Learning to teach English language during the first year: Personal influences and challenges. Teaching and Teacher Education, 19, 95-111.

Farrell, T. S. C. (2015a). Second language teacher education: A reality check. In T. S. C. Farrell (Ed.), International perspectives on English language teacher education (pp. 1-15). Houndsmill Basingstoke: Palgrave Macmillan. 
Farrell, T. S. C. (Ed.). (2015b). International perspectives on English language teacher education: innovations from the field. Houndsmill Basingstoke: Palgrave Macmillan.

Flognfeldt, M. E. (2015). Dia(b)log(g) som didaktisk speil [The dia(b)log as a didactic mirror]. In H. Christensen \& R. S. Stokke (Eds.), Samtalenes didaktiske muligheter [The didactic potential of dialogue] (pp. 123-140). Oslo: Gyldendal Akademisk.

Flognfeldt, M. E. \& Chvala, L. A. (2013). Klasseledelse for læring i språkfaget engelsk [Management for learning in English as a school subject]. In H. Christensen \& I. Ulleberg (Eds.), Klasseledelse, fag og danning [Class management, school subjects and Bildung] (pp. 107-124). Oslo: Gyldendal Akademisk.

Freeman, D. (2002). The hidden side of the work: Teacher knowledge and learning to teach. A perspective from north American educational research on teacher education in English language teaching. Language Teaching, 35(01), 1-13.

Giovanelli, M. (2015). Becoming an English language teacher: Linguistic knowledge, anxieties and the shifting sense of identity. Language and Education, 29(5), 416-429.

Haukås, Å. (2014). Lærerens forestillinger om språkundervisningen [Teacher beliefs about language education]. In C. Bjørke, M. Dypedahl, \& G.-A. Myklevold (Eds.), Fremmedspråksdidaktikk [Foreign language didactics] (pp. 248-260). Oslo: Cappelen Damm Akademisk.

Hestetræet, T. (2010). Teacher cognition and the teaching and learning of EFL vocabulary. In A. Hasselgreen, I. Drew, \& B. Sørheim (Eds.), The young language learner: Research-based insights into teaching and learning (pp. 177-190). Bergen: Fagbokforlaget.

Jessner, U. (2008). Teaching third languages: Findings, trends and challenges. Language Teaching, 41(01), 15-56. doi: http://dx.doi.org/10.1017/S0261444807004739

Kumaravadivelu, B. (2003). Beyond methods: Macrostrategies for language teaching. Yale University.

Lampert, M. \& Graziani, F. (2009). Instructional activities as a tool for teachers' and teacher educators' learning. The Elementary School Journal, 109(5), 491-509.

Lortie, D. (1975). Schoolteacher. A sociological study. London: University of Chicago Press.

Macalister, J. (2012). Pre-service teacher cognition and vocabulary teaching. RELC Journal, 43(1), 99-111.

Maugesten, M. \& Mellegård, I. (2015). Profesjonelle læringsfellesskap for lærere i videreutdanning - utvikling i kunnskapskulturen [Professional learning communities for teachers in further education - Developing a culture of knowledge]. Acta Didactica Norge, 9(1), 1-20.

Nation, P. (2007). The four strands. Innovation in Language Learning and Teaching, 1(1), 213.

Oolbekkink-Marchand, H. W., van der Steen, J., \& Nijveldt, M. (2014). A study of the quality of practitioner research in secondary education: Impact on teacher and school development. Educational Action Research, 22(1), 122-139.

Opfer, V. D. \& Pedder, D. (2011). Conceptualizing teacher professional learning. Review of Educational Research, 81(3), 376-407.

Postholm, M. B. (Ed.). (2012). Lcereres læering og ledelse av profesjonsutvikling [Teacher learning and the management of professional development]. Bergen: Fagbokforlaget.

Postholm, M. B. \& Rokkones, K. (2012). Læreres profesjonelle utvikling: En review av forskning om hvordan lærere lærer [Teachers' professional development: A review of research into how teachers learn]. In M. B. Postholm (Ed.), Læreres lcring og ledelse av profesjonsutvikling [Teacher learning and the management of professional development] (pp. 21-49). Trondheim: Tapir Akademisk Forlag. 
Putnam, R. T. \& Borko, H. (2000). What do new views of knowledge and thinking have to say about research on teacher learning? Educational Researcher, 29(1), 4-15.

Rindal, U. (2014). What is English? Acta Didactica Norge, 8(2), 1-17.

Simensen, A. M. (2014). Skolefaget engelsk. Fra britisk engelsk til mange slags "engelsker" og veien videre [The school subject English: From British English to many different Englishes - and the way ahead]. Acta Didactica Norge, 8(2), 1-18.

Sjølie, E. (2014). The role of theory in teacher education: Reconsidered from a student teacher perspective. Journal of Curriculum Studies, 46(6), 729-750. doi: http://dx.doi.org/10.1080/00220272.2013.871754

Surkalovic, D. (2014). Forbereder grunnskolelærerutdanningen engelsklærere for undervisning i engelsk for tredjespråk i Norge? [Does initial teacher education prepare English teachers in Norway for the teaching of English as a third language?] Acta Didactica Norge, 8(2), 1-17.

Vescio, V., Ross, D., \& Adams, A. (2008). A review of research on the impact of professional learning communities on teaching practice and student learning. Teaching and Teacher Education, 24, 80-91.

Warford, M. K. (2011). The zone of proximal teacher development. Teaching and Teacher Education, 27, 252-258.

Watson, A. (2015). The problem of grammar teaching: A case study of the relationship between a teacher's beliefs and pedagogical practice. Language and Education, 29(4), 332-346.

Wright, T. (2010). Second language teacher education: Review of recent research on practice. Language Teaching, 43(03), 259-296. doi: http://dx.doi.org/10.1017/S0261444810000030

Zeichner, K. (2008). A critical analysis of reflection as a goal for teacher education. Educ. Soc., 29(103), 1-10.

Zeichner, K. (2010). Rethinking the connections between campus courses and field experiences in college- and university-based teacher education. Journal of Teacher Education, 61(1-2), 89-99. 